\title{
HUBUNGAN KERJA PARUH WAKTU DENGAN PRESTASI AKADEMIK MAHASISWA JURUSAN PENDIDIKAN EKONOMI UNIVERSITAS NEGERI SURABAYA ANGKATAN 2015
}

\author{
Lovenda Yuria Linggasari \\ Program Studi S1 Pendidikan Ekonomi, Fakultas Ekonomi, Universitas Negeri Surabaya \\ email : lovendalinggasari@mhs.unesa.ac.id

\section{Riza Yonisa Kurniawan} \\ Program Studi S1 Pendidikan Ekonomi, Fakultas Ekonomi, Universitas Negeri Surabaya \\ email : rizakurniawan@unesa.ac.id
}

\begin{abstract}
Abstrak
Kebutuhan semakin kompleks seiring berkembangnya zaman. Banyaknya biaya hidup yang dibutuhkan saat jauh dari orang tua membuat mahasiswa mencari kerja paruh waktu dengan tujuan untuk mendapatkan sumber dana tambahan demi memenuhi kebutuhan. Tujuan penelitian ini adalah memperoleh deskripsi tentang hubungan antara kerja paruh waktu dengan prestasi akademik mahasiswa Pendidikan Ekonomi Universitas Negeri Surabaya Angkatan 2015. Metode yang digunakan yaitu penelitian sensus dengan teknik pengambilan sample jenuh terhadap 56 mahasiswa yang bekerja paruh waktu. Sedangkan untuk menganalisis data digunakan teknik analisis korelasi Karl Pearson. Hasil penelitian menunjukkan bahwa terdapat hubungan yang signifikan anatara kerja paruh waktu dan prestasi akademik dengan ditunjukkan pada Uji-T yaitu 0,013 < 0,05. Selain itu dengan analisis korelasi Karl Pearson menunjukkan angka 0,330 yang menunjukkan adanya hubungan yang cukup tinggi.
\end{abstract}

Kata Kunci: kerja paruh waktu, prestasi akademik

\section{Abstract}

Human needs more complicated in this era. Students who study aboard start to get part time job for some money to fulfill their needs because high cost of living when they aboard. Purpose of this study is to describe the relationship between parttime work and academic achievement from 2015-enrollment-year student State University of Surabaya Economic Education Department. In this study used census research with saturated samples on 56 part time jobber. While for analyze data using Karl Pearson correlation analysis. The results showed that there was a significant relationship between part-time work and academic achievement as shown in the T-Test of $0.013<0.05$. In addition, the Karl Pearson correlation analysis shows a number of 0.330 which indicates a fairly high relationship.

Keywords: part time work, academic achievement

\section{PENDAHULUAN}

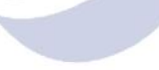

Kebutuhan manusia pada masa kini lebih

dengan pemerintah membantu dalam pembangunan bangsa. Disamping menyiapkan sumber daya yang berkualitas, diharapkan seseorang juga dapat memahami kompleks dibandingkan masa lalu seiring dengan perubahan zaman. Macam kebutuhan yang diperlukan untuk menunjang kelangsungan hidup dibedakan menjadi kebutuhan primer, sekunder, dan tersier. Salah satu contoh kebutuhan primer yang sangat penting bagi manusia di masa ini adalah pendidikan. Kebutuhan akan pendidikan dianggap penting saat ini karena pendidikan nantinya akan mempersiapkan sumber daya manusia. Melalui ilmu yang disampaikan oleh tenaga pendidik, besar harapan bangsa ini nantinya untuk memiliki sumber daya manusia yang berkualitas untuk bersama-sama berbagai peranan dalam masyarakat sehingga pendidikan juga akan berguna ketika seseorang memainkan perannya dalam masyarakat.

Selain pemaparan tentang fungsi pendidikan diatas, terdapat beberapa fungsi pendidikan lain menurut para ahli. Salah satunya adalah fungsi pendidikan menurut Siswoyo, dkk (2007), "pendidikan mempunyai fungsi (1) menyiapkan sebagai manusia, (2) menyiapkan tenaga kerja dan (3) menyiapkan warga negara yang baik". Sesuai dengan teori yang dikemukakan oleh Siswoyo, maka dapat dijelaskan mengenai fungsi pendidikan yang 
pertama yaitu menyiapkan sebagai manusia, dalam praktek pendidikan ditemui adanya pengenalan berbagai peran yang ada dalam masyarakat sehingga melalui pendidikan diharapkan ketika individu masuk ke dalam masyarakat dapat memainkan perannya dengan baik. Dalam fungsi menyiapkan tenaga kerja, pendidikan nantinya akan mengajarkan berbagai disiplin ilmu yang ada guna mencetak sumber daya manusia berkualitas. Fungsi pendidikan yang ketiga yaitu menyiapkan warga negara yang baik, hal ini berhubungan dengan pemerintah yang mewajibkan adanya pelajaran kewarganegaraan di tiap jenjang pendidikan dengan harapan nantinya mampu memahami hak dan kewajibannya dalam masyarakat sehingga berkelakuan sesuai norma yang ada.

Pendidikan formal yang ada di Indonesia diawali dari jenjang Sekolah Dasar, Sekolah Menengah Pertama, Sekolah Menengah Atas dan selanjutnya dapat dilanjutkan pada jenjang Perguruan Tinggi. Namun jumlah Perguruan Tinggi terbatas, tidak seluruh kota di Indonesia dapat memberikan fasilitas pendidikan ini sehingga sebagian generasi muda memberanikan diri berpindah tempat tinggal untuk melanjutkan pendidikan ke jenjang yang lebih tinggi. Banyaknya beasiswa yang tersedia juga membuat para generasi muda lebih bersemangat untuk berusaha mengejar bangku Perguruan Tinggi. Nantinya setelah menjalani berbagai seleksi, siswa lulusan Sekolah Menengah Atas ini beberapa diantaranya akan menjadi mahasiswa di Perguruan Tinggi. Dalam menjalani masa pendidikan di Perguruan Tinggi, sebagian mahasiswa memilih merantau ke kota lain yang membuatnya jauh dari orang tua, sehingga mereka yang biasanya menggunakan uang saku untuk keperluan pribadi pada akhirnya harus benar benar mengatur uang sakunya untuk memenuhi kebutuhan hidupnya sehari-hari.

Sesuai dengan fungsi pendidikan yang telah dijabarkan sebelumnya yaitu menyiapkan tenaga kerja, dengan adanya niat melanjutkan pendidikan hingga perguruan tinggi diharapkan para mahasiswa dapat menuntut ilmu agar kedepannya dapat menjadi tenaga kerja yang memiliki sumber daya manusia berkualitas yang membuatnya bisa mendapatkan jenjang karir untuk memenuhi kebutuhan hidupnya. Menurut Erviana, dkk (2015) "salah satu bentuk persiapan karir yang dapat dilakukan oleh mahasiswa adalah dengan bekerja sambilan".

Fenomena kuliah sambil bekerja saat ini banyak kita temui. Dengan adanya mahasiswa yang mencari pekerjaan paruh waktu ini dapat menguntungkan kedua belah pihak, selain menghasilkan pendapatan tambahan bagi mahsiswa untuk memenuhi kebutuhannya di sisi lain juga menguntungkan pemilik usaha karena uang yang dikeluarkan untuk memberikan gaji kepada mahasiswa lebih rendah daripada harus merekrut lulusan sarjana. Banyaknya peluang pekerjaan di Surabaya juga menjadi salah satu faktor pendukung bagi mahasiswa pencari pekerjaan paruh waktu. Didukung dengan adanya perkembangan teknologi yang semakin maju, mulai bermunculan situs resmi pencarian lowongan pekerjaan paruh waktu bagi mahasiswa, seperti www.jobstreet.co.id, www.karir.com, www.jobindo.com, dan banyak situs lainnya. Saat ini mulai banyak dicari pekerjaan dengan sistem online, misalnya sebagai translator, content writer, data entry, Social Media Administrator, atau designer. Hal ini disebabkan karena bekerja dengan sistem online lebih menarik bagi kalangan mahasiswa yang ingin bekerja namun tidak memiliki kendaraan pribadi, pekerjaan sistem online memungkinkan mereka mengerjakan pekerjaannya di depan laptop saja tanpa perlu pergi ke kantor. Bagi mahasiswa yang memiliki kendaraan pribadi, bergabung dengan ojek online lebih menarik, baik bergabung dengan Grab maupun Gojek.

Banyak faktor yang menjadi latar belakang seorang mahasiswa mengambil keputusan untuk kuliah sambil bekerja, salah satunya masalah finansial. Tidak semua mahasiswa berasal dari kalangan mampu sehingga beberapa mahasiswa yang kesulitan memenuhi kebutuhan memutuskan untuk bekerja sebagai tambahan penghasilan mereka. Sebagian dari mahasiswa yang kekurangan dalam hal finansial ini juga benar benar 
menggantungkan biaya hidupnya pada bantuan dari beasiswa, misalnya saja beasiswa bidik misi. Faktor lain yang mendukung mahasiswa dalam mencari pekerjaan paruh waktu adalah keinginan untuk hidup mandiri dan tidak bergantung pada orang tua. Selain itu mahasiswa juga mencari pekerjaan paruh waktu karena mengisi waktu luang mengingat jadwal perkuliahan yang sudah tidak terlalu padat. Seperti yang telah dikemukakan oleh Daulay (2009) "mahasiswa yang kerja paruh waktu (part time) dilatarbelakangi oleh masalah ekonomi, mengisi waktu luang, hidup mandiri dan mencari pengalaman". Sedangkan menurut Jacinta dalam Dudija (2011) "yang mendasari seorang mahasiswa untuk bekerja diantaranya adalah kebutuhan finansial, kebutuhan sosial relasional, dan kebutuhan aktualisasi diri”.

Berdasarkan pendapat yang telah dikemukakan Daulay dan Jacinta diatas, dapat disimpulkan bahwa terdapat banyak hal yang melatarbelakangi seorang mahasiswa dalam mengambil keputusan menjadi pekerja paruh waktu, salah satunya karena kurangnya uang saku yang diberikan orang tua, alasan ini masuk dalam kategori kebutuhan ekonomi yang juga merupakan alasan utama mahasiswa dalam mencari pekerjaan paruh waktu. Alasan kedua yaitu adanya kebutuhan sosial relasional yang dapat diwujudkan saat bekerja dengan banyaknya bergaul bersama orang baru yang ada di sekitarnya. Hal ini dapat berdampak juga pada pola pikir mahasiswa mengingat semakin banyak menemui berbagai macam orang semakin terbuka pula cara berfikirnya. Alasan ketiga adalah adanya kebutuhan aktualisasi diri dimana mahasiswa yang bekerja memiliki kesadaran bahwa dirinya memiliki potensi yang dapat dikembangkan sebagai sebuah wujud dari aktualisasi diri.

Dengan berbagai macam alasan tersebut, akhirnya mahasiswa memutuskan untuk mencari pekerjaan. Keputusan ini akhirnya diwujudkan dalam berbagai macam pekerjaan paruh waktu yang tersedia. Jam kerja yang kurang dari 8jam sehari masih memungkinkan untuk mereka menyisihkan waktu belajar dan istirahat.

Tidak hanya terjadi di Indonesia, penelitian yang dilakukan Farhana, dkk (2015) pada 67 responden dari
Faculty of Education, Universiti Teknologi MARA, Malaysia menghasilkan sebuah kesimpulan bahwa adanya perbedaan yang cukup signifikan pada aspek kecerdasan emosi mahasiswa yang bekerja paruh waktu dan penuh waktu. Temuan ini menunjukkan fakta bahwa dalam menjalani sebuah pekerjaan, seringkali mahasiswa dihadapkan pada pilihan yang harus membuatnya berfikir berkali-kali sebelum memutuskan untuk menjalaninya. Pola pikir seperti ini yang membuat kecerdasan emosional mahasiswa yang bekerja lebih matang dibandingkan mahasiswa yang tidak bekerja.

Pada kenyataannya, meskipun terlihat menyenangkan namun kuliah sambil bekerja merupakan hal yang rumit. Bekerja di sela sela waktu kuliah memiliki dampak yang positif maupun negatif bagi mahasiswa. Salah satu dampak negatif yang ditimbulkan dari kuliah sambil bekerja adalah kelelahan karena terlalu banyak aktifitas yang dilakukan sehingga waktu beristirahat menjadi kurang. Ketika mahasiswa sudah merasa lelah, mahasiswa cenderung memilih untuk beristirahat dan mengesampingkan kewajibannya dalam mengerjakan tugas ataupun belajar untuk materi yang akan dibahas dalam pertemuan perkuliahan selanjutnya. Sehingga sebagian mahasiswa yang bekerja merasa belum meiliki persiapan matang untuk mengikuti jadwal perkuliahan dikarenakan belum mengerjakan tugas dan belum mempelajari materi. Hal inilah yang berdampak langsung pada prestasi akademik mahasiswa.

Menurut Gleason dalam Metriyana (2014) bahwa

kesempatan memperoleh pekerjaan setelah lulus kuliah akan lebih besar pada mahasiswa yang pernah kuliah sambil bekerja, tidak dapat dipungkiri bahwa atasan pasti lebih memilih mereka yang pernah memiliki pengalaman kerja dibanding yang belum pernah bekerja. Selain itu menurut Dadgar dalam Metriyana (2014) bahwa ditemukan fakta dari wawancara yang telah dilakukan pada mahasiswa yang putus kuliah yaitu mereka mengakui bahwa tidak mampu dalam menyeimbangkan kegiatan perkuliahan dan perkerjaan tersebut yang akhirnya membuat prestasi akademiknya tidak memenuhi standar dan berujung dengan putus kuliah. Hasil 
penelitian yang dilakukan oleh Mardelina (2017) pada 205 responden dari Fakultas Ekonomi UNY juga menemukan fakta bahwa prestasi akademik mahasiswa yang tidak bekerja lebih tinggi dibandingkan mahasiswa yang kuliah sambil bekerja karena mereka yang tidak bekerja memiliki lebih banyak waktu untuk fokus dalam hal perkuliahan, baik itu untuk mengerjakan tugas maupun untuk belajar dan tidak ada hal lain yang dapat memecah konsentrasi mereka ketika fokus berkuliah. Hal ini menunjukkan bahwa terdapat adanya hubungan antara ketidakmampuan mahasiswa menyeimbangkan kegiatan bekerja dan perkuliahan dengan prestasi akademik mahasiswa.

Fenomena mengenai mahasiswa yang kuliah sambil kerja juga ditemukan di Universitas Negeri Surabaya. Jurusan yang akan diteliti adalah Jurusan Pendidikan Ekonomi Universitas Negeri Surabaya, peneliti memilih jurusan ini untuk diteliti didasari beberapa hal, yaitu mahasiswa pendidikan ekonomi sudah mendapatkan mata kuliah ekonomi mikro mengenai teori alokasi waktu dimana mahasiswa memilih mengorbankan waktu luangnya untuk bekerja dan mendapatkan penghasilan yang nantinya dapat digunakan untuk memenuhi kebutuhannya. Alasan lainnya adalah jadwal kuliah yang teratur, dimana kelas kelas tiap prodi memiliki jadwal pagi dan siang sehingga memudahkan memilih rentang jam kerja.

Sesuai dengan studi pendahuluan yang sudah peneliti lakukan ternyata faktanya sebagian besar profesi kerja paruh waktu yang dijalani oleh mahasiswa adalah menjadi guru les privat dan membuka online shop. Dalam menjalankan profesi guru les privat ini, beberapa mahasiswa mengaku bahwa adanya murid les ini dapat sekaligus dijadikan eksperimen dalam menerapkan model pembelajaran yang telah dipelajari pada mata kuliah kependidikan. Efek jangka panjangnya, mahasiswa merasa lebih siap dalam menghdapi program Praktek Ajar Nyata yang akan berlangsung pada semester selanjutnya. Selain itu, mahasiswa juga melihat permintaan menjadi guru les privat ekonomi masih sangat besar peluangnya karena ilmu ekonomi yang terus berkembang seringkali membuat orang tua kebingungan dalam menjawab pertanyaan anaknya sehingga memilih untuk mencari guru les privat ekonomi.

Pekerjaan paruh waktu yang cukup diminati mahasiswa jurusan pendidikan ekonomi lainnya yaitu membuka online shop. Rata-rata alasan mahasiswa memilih jenis pekerjaan ini adalah jam kerja yang fleksibel dan dapat dikerjakan dimana saja. Dalam melakukan pekerjaannya ini, mahasiswa juga dapat menerapkan salah satu teori ekonomi yaitu mengenai promosi. Salah satu mahasiswa mengaku sangat terbantu dengan mempelajari teori tersebut sehingga dapat menerapkannya pada online shop miliknya.

Sebagian mahasiswa yang bekerja paruh waktu mengaku bahwa dari penghasilannya bekerja, sebagian kebutuhan dapat terpenuhi tanpa perlu meminta pada orang tua. Namun mereka juga tidak menyangkal bahwa pekerjaan yang mereka lakukan juga menyita waktu luangnya. Hal ini berdampak langsung pada aspek kehidupan lainnya yaitu dalam hal perkuliahan. Kurangnya waktu luang seringkali membuat mahasiswa malas belajar dan mengerjakan tugas karena memilih untuk istirahat dari lelahnya bekerja. Terlebih lagi mereka yang memilih bekerja paruh waktu sebagai guru les nantinya beban pikiran juga akan bertambah, tidak hanya memikirkan tugasnya namun juga memikirkan tugas muridnya.

Terbatasnya waktu belajar dan mengerjakan tugas bagi mahasiswa yang bekerja paruh waktu ini juga memiliki efek domino lain yaitu pada prestasi akademiknya. Ketika mahasiswa merasa lelah bekerja terkadang mereka mengerjakan tugas secara alakadarnya maka dosen juga enggan memberi nilai lebih pada mahasiswa. Oleh karena itu, penelitian berjudul "Hubungan Kerja Paruh Waktu dengan Prestasi Akademik Mahasiswa Jurusan Pendidikan Ekonomi Universitas Negeri Surabaya Angkatan 2015" ini dibuat untuk melihat ada atau tidaknya hubungan bekerja paruh waktu dengan prestasi akademik mahasiswa.

\section{METODE}


Dalam penelitian ini digunakan metode analisis korelasi. Analisis korelasi yakni studi yang membahas tentang derajat hubungan antara variabel satu dengan yang lainnya. Ukuran yang dipakai untuk mengetahui derajat hubungan disebut koefisien korelasi.

Peneliti menggunakan penelitian sensus dengan teknik pengambilan sampel menggunakan sampel jenuh. Sehingga sampel dalam penelitian ini adalah seluruh mahasiswa yang bekerja paruh waktu yang terdapat pada Angkatan 2015 Jurusan Pendidikan Ekonomi Universitas Negeri Surabaya.

Dalam mengambil data, digunakan teknik angket yang bersifat tertutup dan diisi secara langsung oleh responden. Selain angket, digunakan teknik wawancara pada awal penelitian untuk mengetahui keadaan yang sebenarnya terjadi di lapangan.

Teknik analisis data dalam penelitian ini menggunakan Uji Hipotesis yang berfungsi untuk mengetahui apakah terdapat hubungan atau tidak secara signifikan dari variabel bebas. Derajat signifikansi yang digunakan bernilai 0,05. Peneliti juga menggunakan analisis korelasi dengan menggunakan uji koefisien korelasi dimaksudkan untuk mengetahui derajat hubungan antara variabel $X$ yaitu kerja paruh waktu dan variabel $\mathrm{Y}$ yaitu prestasi akademik mahasiswa.

\section{HASIL DAN PEMBAHASAN}

Hasil penelitian menunjukkan dari 56 mahasiswa yang bekerja paruh waktu, jenis pekerjaan yang paling diminati adalah guru yaitu sekitar 36\% dari jumlah responden atau sebanyak 20 mahasiswa. Pekerjaan dalam bidang online shop juga masih diminati oleh sekitar 30\% responden yaitu berjumlah 17 mahasiswa. Sebanyak 3 mahasiswa atau sekitar 5\% dari jumlah responden lebih memlih bekerja pada industri kuliner, baik menjadi pemilik bisnis kuliner maupun menjadi pramusaji di restoran. 5\% responden lainnya atau

sebanyak 3 mahasiswa memilih pekerjaan menjadi public figure yang bekerja sebagai penyanyi, model, dan Master of Ceremony. 2 mahasiswa atau sekitar $4 \%$ responden memilih menjadi penjaga toko serta sisanya sebanyak 11 mahasiswa atau sekitar 20\% responden memiliki pekerjaan paruh waktu lainnya yaitu menjadi bagian dari event organizer, tukang ojek online, pendamping outbond bagi anak TK-SD, melakukan data entry, penyebar brosur, dan translator.

Pada status finansial, sebanyak 64\% responden atau 36 mahasiswa memiliki total pengeluaran perbulan dibawah Rp. 1.000.000,- sedangkan mayoritas responden yaitu sekitar 52\% dari jumlah populasi atau 29 mahasiswa memiliki uang saku dari orang tua dibawah Rp. 500.000,- perbulan sehingga wajar bila mereka bekerja paruh waktu untuk memenuhi kebutuhannya. 30 mahasiswa atau sekitar $54 \%$ responden menghasilkan dibawah Rp. 500.000,- dalam satu bulan untuk mencukupi kebutuhan sehari - harinya saat jauh dari orang tua.

Dalam hal prestasi akademik mahasiswa Jurusan Pendidikan Ekonomi Universitas Negeri Surabaya yang bekerja paruh waktu sebanyak 56 mahasiswa, sebanyak 34 mahasiswa atau sekitar $61 \%$ dari responden menyandang predikat cum laude, predikat sangat memuaskan sebanyak 22 mahasiswa atau 39\%, dan predikat memuaskan sebnayak 0 mahasiswa atau $0 \%$.

Untuk Uji Hipotesis, dilakukan pengolahan data menggunakan aplikasi SPSS 22 dengan taraf signifikansi 0,05 dan jumlah banyaknya responden 56 mahasiswa. Peneliti mendapatkan hasil sebagai berikut : 
Tabel 4.4 Uji T

Correlations

\begin{tabular}{|rc|r|r|}
\hline & & \multicolumn{1}{|c|}{ kerja } & \multicolumn{1}{|c|}{ ipk } \\
\hline kerja & Pearson Correlation & 1 &, 330 \\
& Sig. (2-tailed) & &, 013 \\
& $\mathrm{~N}$ & 56 & 56 \\
\hline ipk & Pearson Correlation &, 330 & 1 \\
& Sig. (2-tailed) &, 013 & \\
& $\mathrm{~N}$ & 56 & 56 \\
\hline
\end{tabular}

${ }^{*}$. Correlation is significant at the 0.05 level (2-tailed).

Pada tabel 4.4 terlihat adanya nilai signifikansi sebesar 0.013 yang berarti kurang dari 0.05 . Hal tersebut menunjukkan variabel kerja paruh waktu memberikan kontribusi pada hubungan dengan prestasi akademik mahasiswa.

Berdasarkan hasil penelitian diatas, seluruh responden setuju bahwa mereka bekerja kurang dari 8jam dalam satu hari sehingga sebagian besar responden masih menyempatkan waktu untuk belajar dan mengerjakan tugas. Namun mahasiswa yang bekerja saat akhir pekan atau hari libur merasa tidak memiliki waktu berlibur tetapi penghasilan yang didapatkan cenderung lebih besar. Hal ini sejalan dengan teori jam kerja dan perbedaan tingkat upah oleh Kaufman \& Hotchkis (1999) yaitu "kenaikan tingkat upah akan membuat waktu luang menjadi lebih mahal, waktu yang lebih tinggi cenderung membuat orang mensubtitusikan waktu leisurenya dengan lebih banyak bekerja inilah yang disebut dengan efek subtitusi (subtitution effect)". Selain itu, fakta di lapangan menunjukkan bahwa para mahasiswa dengan tingkat upah yang relatif tinggi yaitu pada jenis pekerjaan tertentu seperti model, penyanyi, dan Master of Ceremony menyatakan bahwa mereka cenderung mengurangi jam kerja dikarenakan mendapatkan upah yang lebih banyak dibandingkan pada pekerjaan mereka sebelumnya yang memakan banyak waktu namun upah yang diterima lebih rendah. Hal ini sejalan dengan kurva backward bending supply yang menjelaskan bahwa ketika individu menerima tingkat upah lebih tinggi maka individu tersebut akan cenderung mengurangi waktu yang digunakan untuk bekerja.

Masalah baru akan timbul ketika mahasiswa memperbanyak jam kerjanya dan mengurangi alokasi waktu untuk belajar dan mengerjakan tugas. Efek domino dari hal ini adalah menurunnya prestasi akademik mahasiswa. Hasil penelitian ini sama seperti penelitian yang dilakukan Mardelina (2017) dimana hasil penelitiannya menunjukkan bahwa mahasiswa yang kuliah sambil bekerja memiliki keterbatasan waktu dalam belajar dan mengerjakan tugas kuliah. Namun hasil penelitian kali ini menunjukkan mahasiswa masih dapat mempertahankan prestasi akademiknya dalam predikat sangat memuaskan dan cum laude, hal ini menunjukkan bahwa mahasiswa Jurusan Pendidikan Ekonomi Universitas Negeri Surabaya Angkatan 2015 yang bekerja paruh waktu dapat memanajemen waktu dengan baik sehingga masih dapat mempertahankan prestasi akademiknya.

Selain itu, jika dilihat dari status finansial dan butir pertanyaan mengenai alasan mereka bekerja, mahasiswa setuju bahwa mereka bekerja untuk memenuhi kebutuhannya saat di perantauan yang secara langsung memberikan dampak pada keuangan keluarga yaitu meringankan beban orang tua. Di sisi lain, banyak mahasiswa yang tidak setuju bahwa mereka bisa membeli barang yang mereka inginkan dan menabung dari penghasilan mereka, serta sisanya berpendapat bahwa mereka masih merasa kekurangan uang meskipun sudah bekerja paruh waktu. Hasil ini sejalan dengan hasil penelitian Hipjillah (2015) yaitu tingkat konsumsi mahasiswa pekerja paruh waktu bergantung pada tingkat upah sedangkan prestasi akademik mahasiswa dipengaruhi oleh manajemen waktu.

\section{PENUTUP}

\section{Simpulan}

Dari penelitian yang telah dilakukan, ditemukan bahwa durasi kerja mahasiswa yang bekerja paruh waktu kurang dari 8jam per hari, dengan berbagai macam jenis 
pekerjaan dan tingkat pendapatan yang berbeda. Selain itu, prestasi belajar mahasiswa yang bekerja paruh waktu termasuk dalam kategori sangat memuaskan dan cum laude. Sehingga dapat disimpulkan bahwa terdapat hubungan yang signifikan dan cukup kuat antara kerja paruh waktu dengan prestasi akademik mahasiswa.

\section{Saran}

1. Bagi mahasiswa yang bekerja paruh waktu untuk tetap mempertahankan prestasi akademik meskipun waktu untuk belajar berkurang.

2. Bagi mahasiswa yang ingin bekerja paruh waktu untuk mempertimbangkan dengan matang terkait alokasi waktu sehingga kedepannya masih dapat mempertahankan prestasi akademik.

3. Bagi peneliti selanjutnya untuk melakukan penelitian yang lebih menyeluruh pada mahasiswa Fakultas Ekonomi Universitas Negeri Surabaya yang bekerja paruh waktu.

\section{DAFTAR PUSTAKA}

Arikunto, S. 2013. Prosedur Penelitian. Yogyakarta: Rineka Cipta

Daulay, S.F. 2009. Perbedaan Self regulated Learning antara Mahasiswa yang Bekerja dan yang Tidak Bekerja. Medan: Universitas Sumatera Utara.

Dudija, N. 2011. Perbedaan Motivasi Menyelesaikan Skripsi antara Mahasiswa yang Bekerja dengan Mahasiswa yang Tidak Bekerja. Yogyakarta: Universitas Ahmad Dahlan.

Erviana, E., dkk. 2015. Analisis Manajemen Waktu Kerja Part Time di Universitas Negeri Semarang. Semarang: Universitas Negeri Semarang.

Fauziah, W.S. 2015. Hubungan Motivasi Belajar Mahasiswa yang Bekerja dan Tidak Bekerja terhadap Prestasi Akademik (IPK). Jakarta: UIN Syarif Hidayatullah.

Hipjillah, A. 2015. Mahasiswa Bekerja Paruh Waktu; antara Konsumsi dan Prestasi Akademik. Malang: Universitas Brawijaya.

Jayanti, E.D. 2012. Regulasi Diri Mahasiswa Bekerja Paruh Waktu. Skripsi: Dipublikasikan.
Mardelina, E. 2017. Pengaruh Kerja Part-Time terhadap Aktivitas Belajar dan Prestasi Akademik Mahasiswa Fakultas Ekonomi Universitas Negeri Yogyakarta. Yogyakarta: Universitas Negeri Yogyakarta.

Metriyana, M. 2014. Studi Komparatif Pengaruh Motivasi, Perilaku Belajar, Self- Efficacy dan Status Kerja terhadap Prestasi Akademik antara Mahasiswa Bekerja dan Mahasiswa Tidak Bekerja. Semarang: Universitas Diponegoro.

Purwanto, H. dkk. 2013. Perbedaan Hasil Belajar Mahasiswa yang Bekerja dengan Tidak Bekerja Program Studi Pendidikan Teknik Bangunan Jurusan Teknik Sipil FT-UNP", Jurnal CIVED ISSN 2302-334. Padang: Universitas Negeri Padang.

Ridwan. 2006. Aplikasi Statistika dan Metode Penelitian Untuk. Administrasi dan Manajemen. Bandung: Dewa Ruci.

Sarwono, Jonathan. 2006. Metode Penelitian Kuantitatif dan Kualitatif. Yogyakarta: Graha Ilmu.

Sardiman A.M. 2001. Interaksi dan Motivasi Belajar Mengajar. Jakarta: Raja Grafindo Persada.

Setyadharma. 2010. Uji Asumsi Klasik Dengan SPSS. Semarang: Universitas Negeri Semarang.

Siregar, S. 2010. Statistika Deskriptif untuk Penelitian. Jakarta: Raja Grafindo Persada.

Sugiyono. 2017. Metode Penelitian Kuantitatif, Kualitatif, dan R\&D. Bandung: CV Alfabeta.

Sukardi. 2011. Metodologi Penelitian Pendidikan. Jakarta: Bumi Aksara.

Sumarsono, Sonny. 2003. Ekonomi Manajemen Sumber Daya Manusia dan Ketenagakerjaan. Yogyakarta: Graha Ilmu.

Syah, M. 2001. Psikologi Pendidikan. Bandung: PT. Remaja Rosdakarya.

Witherington, C. 2003. Psikologi Pendidikan Terjemahan M. Ngalim Purwanto. Jakarta: Remaja Rindu Jaya.

Yunus, F. W. 2015. Comparative Study of Part-Time and Full-Time Students, Emotional Intelligence, Psychological Well-Being and Life Satisfactions in the Era of New Technology. Procedia - Social and Behavioral Sciences. 170. $234-242$. 